\title{
PENGARUH SENTIMEN DI SOSIAL MEDIA DENGAN HARGA SAHAM PERUSAHAAN
}

\author{
Musthofa Galih Pradana',Azriel Christian Nurcahyo²,Pujo Hari Saputro ${ }^{3}$ \\ ${ }^{1,3}$ Universitas Alma Ata \\ Yogyakarta, Indonesia \\ ${ }^{2}$ STIM Shanti Bhuana \\ Bengkayang, Kalimantan Barat \\ 1'mgalihpradana@almaata.ac.id, ${ }^{2}$ azriel@shantibhuana.ac.id, ${ }^{3}$ pujo@almaata.ac.id
}

\begin{abstract}
Abstrak
Sentimen adalah proses komputasional dalam mengidentifikasi dan mengategori opini-opini dalam bentuk potongan teks, khususnya untuk mengukur maksud si pembuat potongan teks terhadap topik tertentu, dapat bernada positif, negatif, atau netral. Dalam konteks layanan perusahaan, sentimen yang sering muncul biasanya adalah sentiment yang bernilai positif dalam bentuk pujian dan apresiasi maupun sentiment bernilai negatif dalam bentuk complain. Ketika komplain dilakukan oleh pelanggan, maka pihak perusahaan harus dapat melakukan tindakan untuk menanggulangi komplain tersebut, yang dimungkinkan dapat berimbas terhadap kredibilitas perusahaan, bahkan dapat berimbas pada harga saham. Sosial media menjadi tempat yang dapat digunakan untuk menyampaikan keluhan maupun review positif dari pelanggan terhadap layanan yang diberikan oleh perusahaan. Proses analisis sentimen pelanggan terhadap layanan perusahaan perlu dilakukan untuk mengetahui seberapa besar jumlah sentimen yang muncul menggunakan metode KNN dengan studi kasus pada perusahaan telekomunikasi di Indonesia. Kemudian dilakukan analisis regresi untuk menilai apakah jumlah sentimen pelanggan berpengaruh terhadap harga saham perusahaan. Penelitian ini menghasilkan sentimen positif sebesar $16 \%$, sentimen negatif sebesar $78 \%$ dan sentimen netral sebesar $6 \%$. Metode KNN menghasilkan akurasi paling tinggi sebesar $79,06 \%$ pada cross validation $=4$. Jumlah sentimen negatif dan harga saham memiliki nilai regresi dan nilai korelasi sebesar 0,46 atau dengan kata lain tidak memiliki keterikatan satu sama lain. Sentimen positif menghasilkan nilai regresi dan korelasi sebesar 0,02 dengan artian memiliki keterikatan satu sama lain.
\end{abstract}

Kata Kunci: Sentimen, KNN,Regresi, Cross Validation.

\begin{abstract}
Sentiment is a computational process in identifying and categorizing opinions in the form of pieces of text, specifically to measure the intent of the creator of the piece of text to a certain topic, can be positive, negative, or neutral. In the context of corporate services, the sentiment that often arises is usually positive sentiment in the form of praise and appreciation and negative sentiment in the form of complaints. When a complaint is made by a customer, then the company must be able to take action to overcome the complaint, which is possible to have an impact on the company's credibility, and even can affect the stock price. Social media is a place that can be used to submit complaints and positive reviews from customers about the services provided by the company. The process of analyzing customer sentiments for company services needs to be done to find out how much sentiment appears using the KNN method with a case study on telecommunications companies in Indonesia. Then a regression analysis is performed to assess whether the amount of customer sentiment affects the company's stock price. This research resulted in positive sentiment of $16 \%$, negative sentiment of $78 \%$ and neutral sentiment of $6 \%$. The KNN method produces the highest accuracy of $79.06 \%$ at cross validation $=4$. The number of negative sentiments and share prices have a regression value and a correlation value of 0.46 or in other words do not have an attachment to each other. Positive sentiments produce a regression value and correlation of 0.02 in the sense of having an attachment to each other.
\end{abstract}

Keywords: Sentiment, KNN, Regression, Cross Validation. 


\section{PENDAHULUAN}

Sentimen Negatif merupakan opini yang dikeluarkan di media sosial yang memiliki kesan kurang baik bagi pihak yang disebut, sebaliknya sentimen positif menimbulkan kesan yang baik bagi pihak yang terlibat atau yang disebutkan. Menurut Lovelock \& Wright (2002) komplain adalah bentuk ekspresi formal tentang ketidaksukaan atau ketidakpuasan terhadap beberapa aspek yang diterima seseorang. Komplain sangat wajar diterima oleh sebuah perusahaan baik dari aspek produk maupun layanan yang diberikan belum mampu memuaskan keiginan pelanggan. Perusahaan harus siap dengan segala bentuk komplain yang bias saja diterima. Di era media sosial yang semakin maju, semakin canggih menyampaikan keluhan menjadi sangat mudah, pelanggan tinggal mengakses media sosial dan berharap keluhan yang dialami segera ditindaklanjuti dengan cepat, dibandingkan melayangkan komplain secara konvensional.

Perusahaan harus memberikan pelayanan semaksimal mungkin untuk meminimalisir adanya keluhan pelanggan. Keluhan yang disampaikan oleh pelanggan di media sosial bisa saja dapat membentuk stigma buruk untuk perusahaan, karena sifat media sosial yang tidak ada sekat membuat siapapun dapat melihat komplain yang dilakukan oleh pelanggan lainnya. Hal ini dapat berimbas pada kredibilitas perusahaan, bahkan bisa saja calon pelanggan memutuskan untuk tidak jadi berlangganan atau menggunakan jasa dan produk dari perusahaan terkait akibat testimoni yang buruk dari pelanggan lama. Perusahaan tidak boleh mengesampingkan sentimen yang timbul ini. Lebih jauh lagi, komplain juga kemungkinan besar dapat mempengaruhi nilai sebuah perusahaan atau nilai saham yang anjlok seiring banyaknya komplain yang diterima. Sebaliknya sentimen positif pelanggan di sosial media berpeluang memiliki keterikatan terhadap harga saham, karena bukan tidak mungkin bahwa review positif dari seseorang akan menimbulkan keyakinan orang lain yang hendak melakukan mitra bisnis dengan perusahaan.

Berdasarkan permasalahan tersebut, diperlukan sentimen analisis untuk mendapatkan informasi apakah harga saham akan terpengaruh dengan sentimen pada sebuah perusahaan. Sumber data yang akan dijadikan acuan adalah dari sosial media Facebook Perusahaan telekomunikasi di Indonesia dengan menggunakan metode KNN.

\section{Tinjauan Pustaka}

Penelitian tentang sentimen analisis pernah dilakukan oleh Ghaith Abdulsattar dkk penelitian ini bertujuan dalam membuat framework dalam sentimen analisis yang mengklasifikasikan sentimen ke dalam 3 jenis negatif, positif, dan netral. Proses pelabelan dilakukan secara otomatis. Hasilnya dapat mengklasifikasikan harga di pasaran untuk dijadikan bahan pertimbangan pihak terkait seperti investor, perusahaan, dan para peneliti (Abdulsattar dkk., 2018).

Penelitian kedua dibuat oleh Yefeng Ruan dkk, penelitian ini melakukan sentimen di media sosial twitter dan melakukan analisis menggunakan korelasi pearson, dan linier regresion untuk menghasilkan analisis harga pasar (Ruan dkk., 2018). Penelitian tentang data mining juga pernah dituliskan kaharudin dkk, yang 
membandingkan metode KNN dan Naive Bayes. Kesimpulan dari penelitian ini adalah metode yang menghasilkan akurasi yang lebih baik adalah metode KNearestNeighbor dengan nilai $\mathrm{K}=5$ dengan tingkat akurasi 78\% (Kaharudin, Musthofa Galih Pradana, 2019).

Musthofa Galih Pradana pernah menuliskan penggunaan Term Document Matrix dan Wordcloud pada R Studio dalam penelitian text mining. Penelitian menyimpulkan bahwa penerapan term document matrix dan word cloud saling melengkapi dalam proses text mining, dan memudahkan dalam pengolahan informasi berbasis teks(Pradana, 2020). Penelitian selanjutnya dari Rohan Pimprikar dkk, penelitian ini melakukan prediksi harga menggunakan sentimen analisis metode Support Vector Machine dan Linier Regression. Metode SVM menghasilkan akurasi sebesar $60 \%$ dan Linier Regresion menghasilkan $82 \%$ akurasi (Rohan Pimprikar1, S. Ramachandran2, 2017).

Ayman E. Khedr menulis tentang cara memprediksi harga di pasaran menggunakan teknik data mining dan sentimen analisis. Penelitian ini menghasilkan akurasi dari $72.73 \%$ sampai $86.21 \%$ menggunakan metode Naïve Bayes, sedangkan pada percobaan kedua dapat menghasilkan akurasi sebesar 89.80\% (Khedr, 2017). Shri Bharathi dan Angelina Geetha melakukan penelitian tentang prediksi harga di pasaran agar lebih efektif, penelitian in berhasil meningkatkan $14.43 \%$ akurasi prediksi, ketika dibandingkan dengan metode ID3 dan C4.5(Bharathi, 2017).

Berikutnya penelitian dari Nuno Oliveira dkk yang melakukan prediksi harga pasar menggunakan dataset Twitter, penelitian ini berhasil melakukan prediksi returns, volatility, trading volume and survey sentiment indices yang berguna dalam stock market (Oliveira et al., 2017). Penelitian ke 7 dari Abhishek Kumar dkk, yang melakukan analisis sentimen pada financial text, penelitian ini membangun 2 system, yang pertama yakni Support Vector Classifier Logistic Regression, kemudian yang kedua adalah Support Vector Regression menggunakan word embeddings, lexicon features, dan nilai PMI sebagai fitur (Kumar et al., 2017).

Sara Rosenthal dkk melakukan penelitian tentang sentimen analisis dan berhasil memperkenalkan bahasa arabic dalam analisisnya. Klasifikasi tweet dibagi menjadi 2 poin dan 5 poin ordinal scale(Rosenthal et al., 2017). Penelitian Sentimen Analisis juga dilakukan María del Pilar Salas-Zárate dkk yang berhasil mendapatkan kesimpulan akurasi precision $81.93 \%$, recall $81.13 \%$, dan $F$-measure of $81.24 \%$ untuk tema diabetes(Salas-zárate et al., 2017).

Penelitian rujukan terakhir dari Munir Ahmad dkk, penelitian ini menerapakan metode SVM di dalam aplikasi weka yang menghasilkan kesimpulan pada 2 dataset yang digunakan menghasilkan akurasi Self-Driving Cars sebesar $59.91 \%$ dan dataset Apple sebesar 71.2\%(Ahmad \& Ali, 2017).

\section{METODE PENELITIAN}

\section{Metode Pengumpulan Data}

Pengumpulan data dilakukan melalui proses crawling. Proses pengambilan data didapatkan dari sumber sosial media Facebook. Data yang diambil dari Facebook, masih unstructured, masih 
banyak sampah yang perlu diolah di proses pengolahan data. Proses pengumpulan data ditunjukan pada Gambar 1.

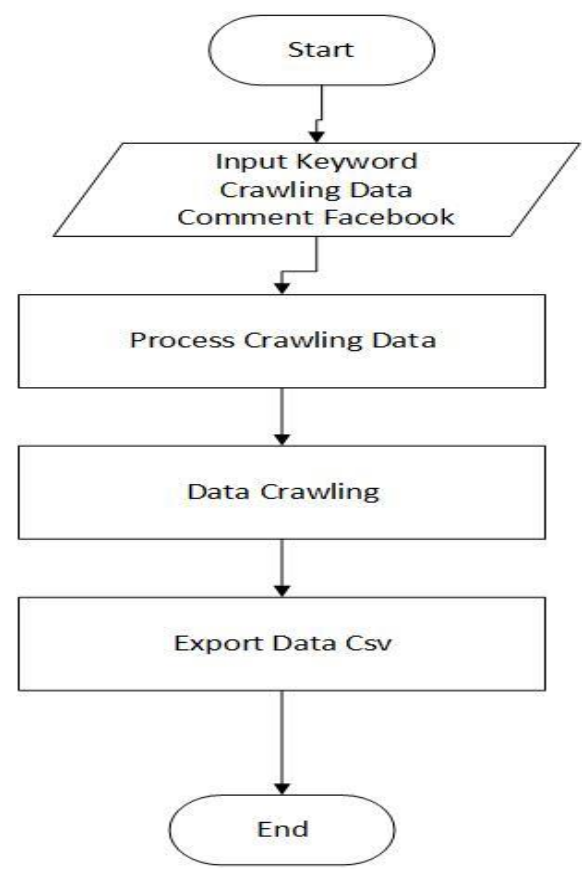

Gambar 1. Alur Pengumpulan Data

\section{MetodePengolahan Data}

Data hasil crawling diolah dan dipilih yang sesuai dengan kebutuhan analisis. Tahap yang dilakukan pada pengolahan data adalah preprocessing, adapun langkahnya adalah :
a. Filtering duplicate
b. Case folding
c. Cleaning
d. Tokenizing / parsing
e. Filtering

\section{Implementasi}

Setelah melalui tahapan pengolahan data dengan preprocesing, maka akan dilakukan proses implementasi ke dalam metode KNN dan di cari hubungannya dengan harga saham menggunakan analisis regresi. Selain itu juga akan dicari kata apa yang sering muncul dalam sentimen pelanggan di sosial media.

\section{Kesimpulan}

Tahap yang terakhir adalah penarikan kesimpulan dari apa yang sudah dikerjakan dari tahap pertama sampai ketiga, sehingga di dapatkan informasi apakah sentiment berpengaruh terhadap harga saham.

\section{HASIL PENELITIAN DAN PEMBAHASAN \\ Dataset}

Dataset yang digunakan dalam penelitian adalah data hasil crawling data di Sosial Media Facebook pada periode Januari 2017 sampai Desember 2018 dengan jumlah data mentah sebanyak 2.850 . Setelah data didapatkan dari facebook. Proses setelah mendapatkan data adalah dengan mengolah dan membersihkan data tersebut sehingga dapat menjadi informasi yang berguna. Dari data awal sejumlah 2850 setelah dibersihkan menjadi 1605 yang selanjutnya dilakukan pemilihan data yang memiliki sentimen terhadap perusahaan. Data detail ditunjukan pada Tabel 1.

Tabel 1. Dataset

\begin{tabular}{ll}
\hline Periode Waktu & $\begin{array}{l}\text { Jumlah } \\
\text { Comment }\end{array}$ \\
\hline Januari 2017 & 257 \\
\hline Februari 2017 & 13 \\
\hline Maret 2017 & 63 \\
\hline April 2017 & 14 \\
\hline Juli 2017 & 38
\end{tabular}




\begin{tabular}{ll}
\hline Agustus 2017 & 45 \\
\hline September 2017 & 150 \\
\hline Oktober 2017 & 316 \\
\hline November 2017 & 57 \\
\hline Desember 2017 & 161 \\
\hline Januari 2018 & 105 \\
\hline Februari 2018 & 163 \\
\hline Maret 2018 & 15 \\
\hline April 2018 & 45 \\
\hline Mei 2018 & 10 \\
\hline Juni 2018 & 36 \\
\hline Juli 2018 & 37 \\
\hline Agustus 2018 & 57 \\
\hline September 2018 & 19 \\
\hline Desember 2018 & 2 \\
\hline Total & $\mathbf{1 6 0 5}$ \\
\hline
\end{tabular}

\section{Pengolahan Data}

Data setelah proses pembersihan data, selanjutnya dilakukan pelabelan sentimen yang dibagi menjadi 3 jenis yaitu sentimen positif, negatif dan netral. Data pengolahan data ditunjukan pada Tabel 2.

Tabel 2. Klasifikasi Sentimen

\begin{tabular}{l}
$\begin{array}{l}\text { Periode Positif Negatif Netral } \\
\text { Waktu }\end{array}$ \\
\hline
\end{tabular}

\begin{tabular}{lccc}
\hline $\begin{array}{l}\text { Januari } \\
\mathbf{2 0 1 7}\end{array}$ & 29 & 227 & 1 \\
\hline $\begin{array}{l}\text { Februari } \\
\mathbf{2 0 1 7}\end{array}$ & 1 & 12 & 0 \\
\hline Maret & 6 & 56 & 1 \\
\hline
\end{tabular}

2017

\begin{tabular}{|c|c|c|c|}
\hline April 2017 & 14 & 0 & 0 \\
\hline Juli 2017 & 14 & 21 & 3 \\
\hline $\begin{array}{l}\text { Agustus } \\
2017\end{array}$ & 0 & 43 & 2 \\
\hline $\begin{array}{l}\text { September } \\
2017\end{array}$ & 19 & 123 & 8 \\
\hline $\begin{array}{l}\text { Oktober } \\
2017\end{array}$ & 85 & 209 & 22 \\
\hline $\begin{array}{l}\text { November } \\
2017\end{array}$ & 0 & 52 & 5 \\
\hline $\begin{array}{l}\text { Desember } \\
2017\end{array}$ & 30 & 115 & 16 \\
\hline $\begin{array}{l}\text { Januari } \\
2018\end{array}$ & 5 & 88 & 12 \\
\hline $\begin{array}{l}\text { Februari } \\
2018\end{array}$ & 19 & 135 & 9 \\
\hline $\begin{array}{l}\text { Maret } \\
2018\end{array}$ & 2 & 13 & 0 \\
\hline April 2018 & 4 & 39 & 2 \\
\hline Mei 2018 & 4 & 6 & 0 \\
\hline Juni 2018 & 7 & 26 & 3 \\
\hline Juli 2018 & 1 & 35 & 1 \\
\hline $\begin{array}{l}\text { Agustus } \\
2018\end{array}$ & 3 & 46 & 8 \\
\hline $\begin{array}{l}\text { September } \\
2018\end{array}$ & 6 & 8 & 5 \\
\hline $\begin{array}{l}\text { Desember } \\
2018\end{array}$ & 1 & 1 & 0 \\
\hline
\end{tabular}

\section{Harga Saham}

Harga saham digunakan sebagai variabel yang akan dicari hubungan dengan jumlah sentimen di comment facebook. Data harga saham yang digunakan adalah periode waktu yang sama dengan periode waktu 
crawling data. Data harga saham ditunjukan pada Tabel 3.

Tabel 3. HargaSaham

\begin{tabular}{ccc}
\hline Periode & $\begin{array}{c}\text { Harga } \\
\text { Saham }\end{array}$ & Keterangan \\
&
\end{tabular}

\begin{tabular}{ccc}
\hline Januari & $1,28 \mathrm{~B}$ & - \\
$\mathbf{2 0 1 7}$ & &
\end{tabular}

\begin{tabular}{|c|c|c|}
\hline $\begin{array}{c}\text { Februari } \\
2017\end{array}$ & $1,49 \mathrm{~B}$ & Naik \\
\hline Maret 2017 & $1,79 \mathrm{~B}$ & Naik \\
\hline April 2017 & $1,58 \mathrm{~B}$ & Turun \\
\hline Juli 2017 & $1,68 \mathrm{~B}$ & Naik \\
\hline $\begin{array}{c}\text { Agustus } \\
2017\end{array}$ & $1,25 \mathrm{~B}$ & Turun \\
\hline $\begin{array}{c}\text { September } \\
2017\end{array}$ & $1,39 \mathrm{~B}$ & Naik \\
\hline $\begin{array}{c}\text { Oktober } \\
2017\end{array}$ & $3,76 \mathrm{~B}$ & Naik \\
\hline $\begin{array}{c}\text { November } \\
2017\end{array}$ & $2,34 \mathrm{~B}$ & Turun \\
\hline $\begin{array}{c}\text { Desember } \\
2017\end{array}$ & $1,29 \mathrm{~B}$ & Turun \\
\hline $\begin{array}{c}\text { Januari } \\
2018\end{array}$ & $583,32 \mathrm{M}$ & Turun \\
\hline $\begin{array}{c}\text { Februari } \\
2018\end{array}$ & $378,00 \mathrm{M}$ & Turun \\
\hline Maret 2018 & $401,99 \mathrm{M}$ & Naik \\
\hline April 2018 & $386,79 \mathrm{M}$ & Turun \\
\hline Mei 2018 & $475,31 \mathrm{M}$ & Naik \\
\hline Juni 2018 & $849,81 \mathrm{M}$ & Naik \\
\hline Juli 2018 & $974,13 \mathrm{M}$ & Naik \\
\hline $\begin{array}{c}\text { Agustus } \\
2018\end{array}$ & $684,02 \mathrm{M}$ & Turun \\
\hline
\end{tabular}

\begin{tabular}{ccc}
\hline $\begin{array}{c}\text { September } \\
\mathbf{2 0 1 8}\end{array}$ & $295,33 \mathrm{M}$ & Turun \\
\hline $\begin{array}{c}\text { Desember } \\
\mathbf{2 0 1 8}\end{array}$ & $462,51 \mathrm{M}$ & Naik \\
& & \\
& & \\
\end{tabular}

\section{Metode KNN}

Metode KNN yang diterapkan untuk mengklasifikasikan data diuji dengan teknik cross validation. Pengujian cross validation merupakan proses membagi data secara acak ke dalam beberapa bagian. Proses pengujian dimulai dengan pembentukan model dengan data pada bagian pertama. Model yang terbentuk akan diujikan pada bagian data yang tersisa. Setelah itu proses akurasi dihitung dengan melihat seberapa banyak data yang sudah terklasifikasi dengan benar. Data hasil pengujian ditunjukan Gambar 2.

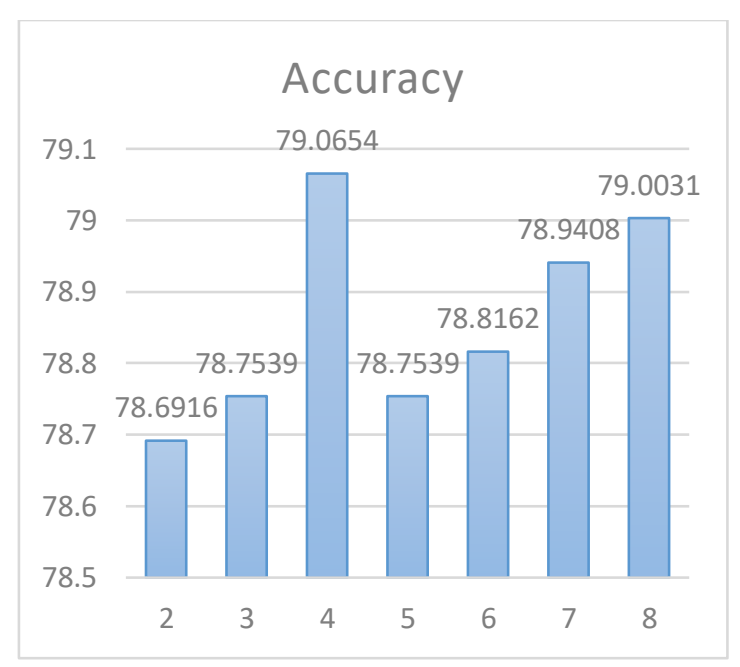

Gambar 2. Akurasi Cross Validation

Berdasarkan pengujian cross validation metode $\mathrm{KNN}$, didapatkan nilai tertinggi pada nilai cross validation $=4$ atau dengan nilai $79,06 \%$. Adapun detail pada nilai cross validation $=4$ ditunjukan pada Tabel 4. 
Tabel 4. Detail Akurasi

Sentimen Precision Recall F-

\section{Measure}

\begin{tabular}{lccc}
\hline Positif & 0,769 & 0,080 & 0,144 \\
& & & \\
\hline Negatif & 0,792 & 0,994 & 0,881 \\
\hline Netral & 0,000 & 0,000 & 0,000
\end{tabular}

Setelah diketahui besaran sentiment analisis pada proses pengolahan data, maka akan dicari apakah pada periode tertentu akan berpengaruh dengan harga saham menggunakan analisis regresi. Analisis regresi yang dilakukan dibagi menjadi 2 yaitu regresi terhadap sentimen positif dan regresi terhadap sentiment negatif.

Ketentuan dalam melakukan analisis regresi sebagai berikut :

Cara membaca korelasi adalah dengan:

Berdasarkan arahnya :

Apabila positif (+) maka hubungannya searah, artinya jika 1 variabel naik maka yang lain ikut naik

Apabila negatif (-) maka hubungannya berlawanan, artinya jika 1 variabel naik maka yang lain turun.

Berdasarkan nilai derajat korelasinya baik positif maupun negatif :

$$
\begin{array}{ll}
0,7 \mathrm{~s} / \mathrm{d} 1 & =\text { kuat } \\
0,4 \mathrm{~s} / \mathrm{d} 0,7 & =\text { sedang } \\
0,2 \mathrm{~s} / \mathrm{d} 0,4 & =\text { rendah } \\
<0,2 & =\text { lemah }
\end{array}
$$

Cara melihat nilai korelasi kedua adalah dengan melihat jika angka probabilitas> 0,05 maka tidak ada hubungan yang signifikan antara kedua variable tersebut dan sebaliknya.
Cara melakukan analisis regresi diperlukan hipotesis sebagai berikut:

H0: Tidak ada hubungan linier antara variabel jumlah sentiment dengan harga saham

H1: Ada hubungan linier antara variable jumlah sentiment dengan harga saham Pengujian dilakukan dengan menggunakan Sig dengan ketentuan:

Jika angka signifikansi< 0,05; H0 ditolak dan $\mathrm{H} 1$ diterima.

Jika angka signifikansi> 0,05; H0 diterima dan $\mathrm{H} 1$ ditolak.

\section{SentimenNegatif}

Nilai korelasi 0,450. Artinya, hubungan kedua variable tersebut sedang. Korelasi positif menunjukkan bahwa hubungan antara jumlah sentiment dengan harga saham searah. Dalam arti jika jumlah sentimen negatif semakin sering maka harga saham akan menurun. Nilai korelasi sebesar 0,46>0,05 = Tidak ada hubungan yang signifikan antar variable. Gambar hasil analisis korelasi ditunjukan pada Gambar 3.

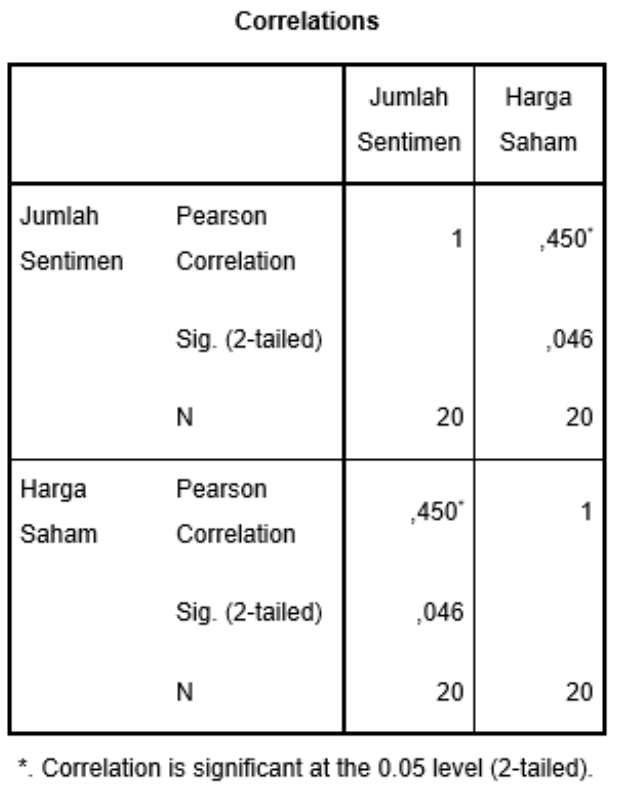

Gambar 3. KorelasiSentimenNegatif 
Besarnya pengaruh variable Jumlah Sentimen terhadap Harga Saham adalah sebesar 20,3\%. Hasil analisis ditunjukan pada Gambar 4.

Model Sumpary

\begin{tabular}{|l|r|r|r|r|}
\hline $\begin{array}{l}\text { Mod } \\
\text { el }\end{array}$ & $\mathrm{R}$ & $\begin{array}{c}\mathrm{R} \\
\text { Square }\end{array}$ & $\begin{array}{c}\text { Adjusted } \mathrm{R} \\
\text { Square }\end{array}$ & $\begin{array}{c}\text { Std. Error } \\
\text { of the } \\
\text { Estimate }\end{array}$ \\
\hline 1 &, $450^{\mathrm{a}}$ &, 203 &, 159 & $\begin{array}{r}967161513 \\
20,033\end{array}$ \\
\hline
\end{tabular}

a. Predictors: (Constant), Jumlah Sentimen.

b. Dependent Variable: Harga Saham

\section{Gambar 4. Analisis Model Summary}

Perhitungan angka signifikansi 0,46 > 0,05; H0 diterima dan H1 ditolak. Artinya ,tidak ada hubungan linier antara kedua variabel, maka sentiment negative tidak mempengaruhi harga saham. Hasil analisis anova ditunjukan pada Gambar 5.

ANOYA

\begin{tabular}{|c|c|c|c|c|c|}
\hline Model & $\begin{array}{l}\text { Sum of } \\
\text { Squares }\end{array}$ & $d f$ & $\begin{array}{l}\text { Mean } \\
\text { Square }\end{array}$ & $\mathrm{F}$ & Sig. \\
\hline $\begin{array}{l}\text { Residu } \\
\text { al } \\
\text { Total }\end{array}$ & $\begin{array}{r}4287132 \\
7990501 \\
5150000 \\
00,000 \\
1683722 \\
5067087 \\
1600000 \\
000,000 \\
2112435 \\
7866137 \\
3120000 \\
000,000\end{array}$ & 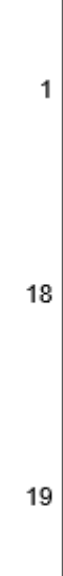 & $\begin{array}{r}4287132 \\
7990501 \\
5150000 \\
00,000 \\
9354013 \\
9261595 \\
3400000 \\
0,000\end{array}$ & 4,583 &, $046^{\mathrm{b}}$ \\
\hline
\end{tabular}

a. Dependent Variable: Harga Saham

b. Predictors: (Constant), Jumlah Sentimen 3

Gambar 5. Analisis Anova Regresi

\section{Sentimen Positif}

Nilai korelasi 0,659. Artinya, hubungan kedua variable tersebut sedang. Korelasi positif menunjukkan bahwa hubungan antara jumlah sentiment dengan harga saham searah. Dalam arti jika jumlah sentiment negative semakin sering maka harga saham akan menurun .Nilai korelasi sebesar $0,02<0,05=$ Ada hubungan yang signifikan antar variable. Gambar hasil analisis korelasi ditunjukan pada Gambar 6.

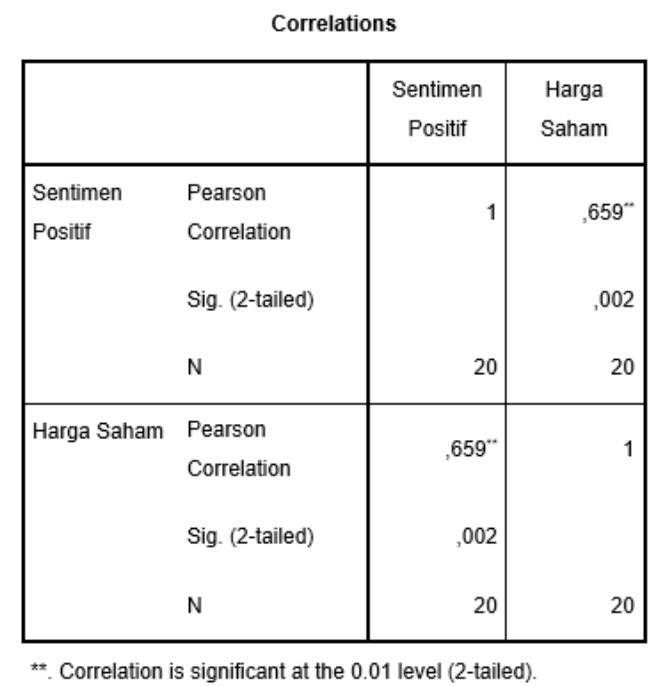

Gambar 6. Korelasi Sentimen Positif

Besarnya pengaruh variable Jumlah Sentimen terhadap Harga Saham adalah sebesar 43,4\%. Hasil analisis ditunjukan pada Gambar 7.

Model Summary ${ }^{\mathrm{b}}$

\begin{tabular}{|l|r|r|r|r|}
\hline $\begin{array}{l}\text { Mode } \\
\text { I }\end{array}$ & R & $\begin{array}{c}\text { R } \\
\text { Square }\end{array}$ & $\begin{array}{c}\text { Adjusted R } \\
\text { Square }\end{array}$ & $\begin{array}{r}\text { Std. Error of } \\
\text { the Estimate }\end{array}$ \\
\hline 1 &, $659^{\circ}$ &, 434 &, 403 & $\begin{array}{r}8146870384 \\
3,636\end{array}$ \\
a. Predictors: (Constant), Sentimen Positif \\
b. Dependent Variable: Harga Saham
\end{tabular}

Gambar 7. Analisis Model Summary 
Perhitungan angka signifikansi 0,02 < 0,05; H0 ditolak dan H1 diterima. Artinya ada hubungan linier antara kedua variabel, maka sentiment positif mempengaruhi harga saham. Hasil analisis anova ditunjukan pada Gambar 8.

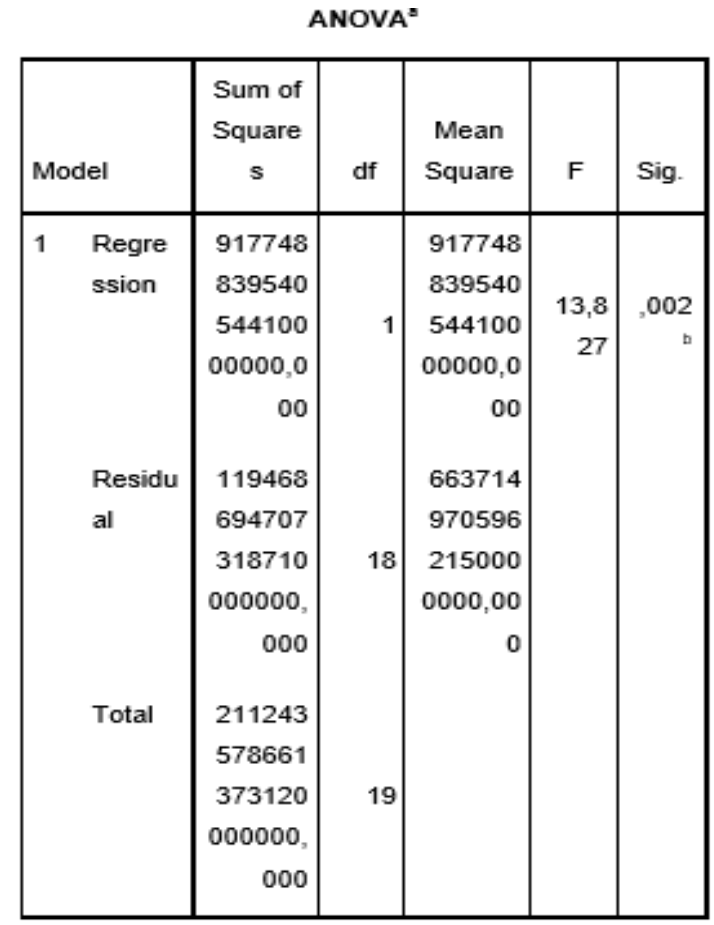

a. Dependent Variable: Harga Saham

b. Predictors: (Constant), Sentimen Positif

Gambar 8.Analisis Anova Regresi

\section{Wordcloud}

Wordcloud merupakan fitur yang dapat digunakan untuk mengindentifikasi kata yang paling sering atau paling banyak digunakan pengguna sosial media saat berinteraksi dengan perusahaan. Pada penelitian ini, sebenarnya kata dengan frekuensi paling tinggi adalah kata nama perusahaan, namun penulis hilangkan untuk menghilangkan personalisasi, beserta kata yang berhubungan dengan produk dan layanannya. Adapun setelah pemilihan kata yang dihilangkantersebut data frekuensi pada wordcloud ditunjukan pada Tabel 5.

Tabel 5. Hasil Wordcloud

\begin{tabular}{c|c}
\hline Kata & Frekuensi \\
\hline Indonesia & 306 \\
Internet & 235 \\
Hari & 223 \\
Tolong & 205 \\
Gangguan & 190 \\
Jaringan & 187 \\
Bayar & 177 \\
Mati & 175 \\
Sampai & 137 \\
Pelanggan & 128 \\
\hline
\end{tabular}

Berdasarkan 10 terbesar kata yang sering digunakan pengguna sosial media, data lebih detail atau lebih banyak tentang kata pada wordcloud ditunjukan pada Gambar 9

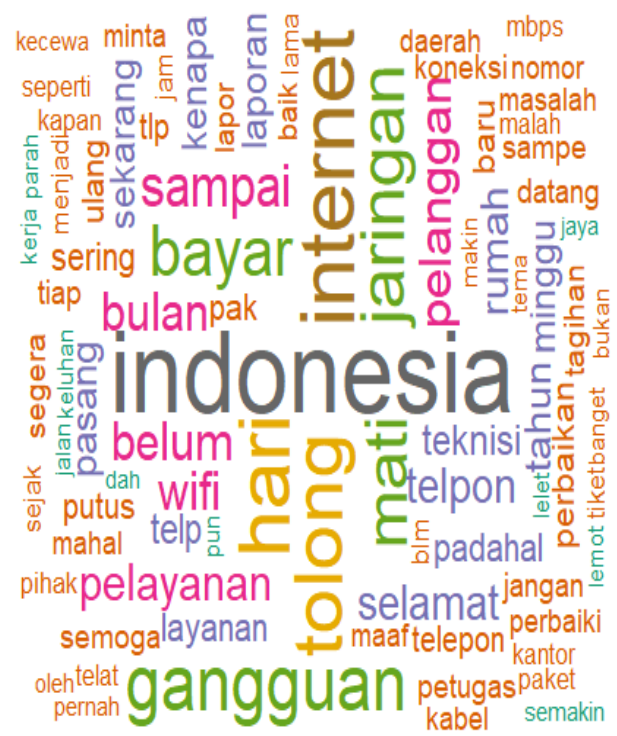

Gambar 9. Wordcloud 100 Kata 


\section{KESIMPULAN DAN SARAN}

Berdasarkan penelitian yang telah dilakukan dapat ditarik kesimpulan sebagai berikut :

1. Sentimen Positif sebesar $16 \%$, sentimen negatif $78 \%$ dan sentimen netral sebesar $6 \%$

2. Sentimen Negatif tidak memiliki hubungan dengan harga saham.

3. Sentimen Positif memiliki hubungan dengan harga saham.

4. Kata yang paling banyak digunakan pengguna adalah Indonesia dengan jumlah sebesar 306 kata.

Adapun saran dalam penelitian ini adalah data dapat diperkaya dari sumber data lainnya seperti Twitter, Youtube, Instagram dan Sosial Media lainnya agar lebih mendapatkan tingkat kepastian yang lebih baik.

\section{DAFTAR PUSTAKA}

Abdulsattar, G., Alkubaisi, A. J., Kamaruddin, S. S., \& Husni, H. (2018). Conceptual Framework for Stock Market Classification Model Using Sentiment Analysis on Twitter Based on Hybrid Nä̈ve Bayes Classifiers. 7, 57-61.

Ahmad, M., \& Ali, I. (2017). Sentiment Analysis of Tweets using SVM. 177(5), 25-29.

Bharathi, S. (2017). Sentiment Analysis for Effective Stock Market Prediction. 10(3), 146-154. https://doi.org/10.22266/ijies2017.063 0.16

Kaharudin, K., Pradana, M. G., \& Kusrini, K. (2019). PREDIKSI CUSTOMER CHURN PERUSAHAAN

\section{TELEKOMUNIKASI}

MENGGUNAKAN NAÏVE BAYES DAN K-NEAREST NEIGHBOR. Informasi Interaktif, 4(3), 165-171.

Khedr, A. E. (2017). Predicting Stock Market Behavior using Data Mining Technique and News Sentiment Analysis. July, 22-30. https://doi.org/10.5815/ijisa.2017.07.0 3

Kumar, A., Sethi, A., Akhtar, S., \& Ekbal, A. (2017). Sentiment Prediction in Financial Text.

Oliveira, N., Cortez, P., \& Areal, N. (2017). The impact of microblogging data for stock market prediction: Using Twitter to predict returns, volatility, trading volume and survey sentiment indices. Expert Systems With Applications, 73, 125-144. https://doi.org/10.1016/j.eswa.2016.1 2.036

Pradana, M. G. (2020). PENGGUNAAN FITUR WORDCLOUD DAN DOCUMENT TERM MATRIX DALAM TEXT MINING.

Rohan Pimprikar1, S. Ramachandran2, K. S. (2017). USE OF MACHINE LEARNING ALGORITHMS AND TWITTER SENTIMENT ANALYSIS FOR STOCK MARKET PREDICTION. 115(6), 521-526.

Rosenthal, S., Farra, N., \& Nakov, P. (2017). Sentiment Analysis in Twitter. 502-518.

Ruan, Y., Durresi, A., \& Alfantoukh, L. (2018). Using Twitter trust network for stock market analysis. KnowledgeBased Systems, 0, 1-12. https://doi.org/10.1016/j.knosys.2018. 01.016

Salas-zárate, M. P., Medina-moreira, J., 
Lagos-ortiz, K., Luna-aveiga, H., Rodríguez-garcía, M. Á., \& Valenciagarcía, R. (2017). Sentiment Analysis on Tweets about Diabetes: An Aspect-Level Approach. 2017. 